\title{
Worldwide survey of Corynebacterium striatum increasingly associated with human invasive infections, nosocomial outbreak, and antimicrobial multidrug-resistance, 1976-2020
}

\author{
Giorgio Silva-Santana ${ }^{1,2,3,4} \oplus$. Cecília Maria Ferreira Silva $a^{1,2} \cdot$ Julianna Giordano Botelho Olivella ${ }^{1,2} \mathbb{D}$. \\ Igor Ferreira Silva ${ }^{1,2} \cdot$ Laís Menegoi Oliveira Fernandes $^{1,2} \cdot$ Bruna Ribeiro Sued-Karam $^{1,2}$. Cíntia Silva Santos ${ }^{1,2}$. \\ Cassius Souza ${ }^{1,2}\left[\right.$ - Ana Luíza Mattos-Guaraldi ${ }^{1,2,3,4}$
}

Received: 2 September 2020 / Revised: 8 January 2021 / Accepted: 14 February 2021 / Published online: 24 February 2021

(c) The Author(s), under exclusive licence to Springer-Verlag GmbH, DE part of Springer Nature 2021

\begin{abstract}
Corynebacterium striatum is part of microbiota of skin and nasal mucosa of humans and has been increasingly reported as the etiologic agent of community-acquired and nosocomial diseases. Antimicrobial multidrug-resistant (MDR) C. striatum strains have been increasingly related to various nosocomial diseases and/or outbreaks worldwide, including fatal invasive infections in immunosuppressed and immunocompetent patients. Although cases of infections by C. striatum still neglected in some countries, the improvement of microbiological techniques and studies led to the increase of survival of patients with $C$. striatum nosocomial infections at different levels of magnitude. Biofilm formation on abiotic surfaces contributes for the persistence of virulent $C$. striatum and dissemination of antimicrobial resistance in hospital environment. Besides that, empirical antibiotic therapy can select multi-resistant strains and transfer intra and interspecies genes horizontally. In this study, a worldwide survey of $C$. striatum human infections and nosocomial outbreaks was accomplished by the analysis of clinical-epidemiological and microbiological features of reported cases from varied countries, during a 44-year period (1976-2020).
\end{abstract}

Keywords Biocides $\cdot$ Biofilm $\cdot$ Corynebacterium striatum $\cdot$ Multidrug-resistance $\cdot$ Neglected pathogen $\cdot$ Nosocomial outbreak

Communicated by Erko Stackebrandt.

Giorgio Silva-Santana

bio.sant@hotmail.com

1 Laboratory of Diphtheria and Corynebacteria of Clinical Relevance, Faculty of Medical Sciences, University of the State of Rio de Janeiro, Rio de Janeiro, RJ, Brazil

2 The Collaborating Centre for Reference and Research on Diphtheria/National Health Foundation/Ministry of Health, Rio de Janeiro, Brazil

3 Health Sciences Center, Institute of Microbiology Paulo de Góes, Federal University of Rio de Janeiro, Rio de Janeiro, RJ, Brazil

4 Centro de Ciências da Saúde (CCS), Universidade Federal do Rio de Janeiro, Instituto de Microbiologia Professor Paulo de Góes, Cidade Universitária, Ilha do Fundão, Rio de Janeiro, Brazil

\section{Introduction}

The Corynebacterium genus, described by Lehmann and Neumann (1896), belongs to Actinobacteria class, Actinomecetales order, and Corynebacteriaceae family (Lehmann and Neumann 1896). Nowadays, Corynebacterium genus has more than 132 highly diversified species and 11 subspecies, with at least 50 species already recognized of medical, veterinary, and biotechnological relevance (Parte 2014; Zasada and Mosiej 2018). Although non-diphtherial Corynebacterium spp. may be part of the human microbiota (amphibionic), varied species have been currently reported as the etiologic agent of human infections (Funke and Bernard 2011; Baio et al. 2013; Bernard et al. 2013; Zasada and Mosiej 2018). For many decades, the pathogenic potential of non-diphtherial Corynebacterium species was neglected, mainly for the difficulty in identification and distinction between colonization and infection (Camello et al. 2003; Martins et al. 2009). However, Corynebacterium species 
identified during laboratorial procedures remain frequently considered as contaminants of clinical specimens and/or underestimated by a variety of health professionals in many countries (Baio et al. 2013; Bernard et al. 2013; Zasada and Mosiej 2018).

A growing number of reports have demonstrated the relevance of Corynebacterium pathogens in the etiology of a variety of infectious processes, in both immunocompromised and immunocompetent patients. Some species have been also described different corynebacterial species as causal agents of infections with high morbidity and mortality rates. Data reflect a tendency towards infection or colonization of patients who have undergone surgical/invasive procedures and a long subsequent hospitalization period, advanced age, neoplastic diseases, organ transplantation, Acquired Immunodeficiency Syndrome (AIDS), diabetes, prolonged antibiotic therapy, as well as procedures such as catheterization, heart valves and prosthetic implants (Martins et al. 2009; Carvalho et al. 2018).

Diphtheria outbreaks and atypical cases of diphtheria localized, and systemic infections cases have been reported in both industrialized and developing countries due to diphtheria toxin (DT)-producing and non-DT-producing C. diphtheriae and C. ulcerans, a zoonotic pathogen (Schröder et al. 2012; Simpson-Lourêdo et al. 2019). Moreover, potentially DT-producer C. pseudotuberculosis, a zoonotic pathogen, have been mainly related to cases of contagious chronic disease, named Caseous Lymphadenitis (CLA) in ruminants (Azevedo Antunes et al. 2018).

Clinical implications due to expression of multidrugresistance (MDR) profiles by non-DT-producing Corynebacterium species have been reported among hospitalized patients infected with $C$. afermentans, $C$. amycolatum, $C$. jeikeium, C. pseudodiphtheriticum, C. striatum, and $C$. urealyticum (Renom et al. 2007; Martins et al. 2009; Carvalho et al. 2018). Clones presenting natural and/or acquired resistance to antimicrobials have been identified, such as $C$. macginleyi, C. minutissimum, and C. xerosis, both in and out of hospitals' environments (Renom et al. 2007; Reddy et al. 2012). Studies have shown that the prevalence of those MDR clones depends on geographic location, beyond the constant acquisition of genes from other species, that grant resistance phenotypes to new antimicrobials (Zasada and Mosiej 2018; Ramos et al. 2019).

In this study, a worldwide survey of $C$. striatum human infections and nosocomial outbreaks was accomplished by the analysis of clinical-epidemiological and microbiological features of reported cases from varied countries, during a 44-year period (1976-2020).

\section{Corynebacterium striatum infections features and nosocomial outbreaks}

Corynebacterium striatum exhibiting MDR profiles have been isolated from the respiratory tract of patients with community-acquired infections and nosocomial diseases. Since C. striatum is a participant in microbiota of the skin, and nasal mucosa of humans, this pathogen also remains recognized as contaminant and systematically disregarded during clinical and laboratory diagnosis in many opportunities (Lee et al. 2005; Bernard et al. 2013). An increasing number of cases of invasive infections by $C$. striatum are reported in immunocompromised and immunocompetent individuals, including: bacteremia and sepsis (Renom et al. 2007; Wong et al. 2010), septic arthritis (Cone et al. 1998; Scholle 2007), endocarditis, meningitis (Weiss et al. 1996; Oliva et al. 2010), osteomyelitis (Fernández-Ayala et al. 2001; Scholle 2007), sinusitis (Heidemann et al. 1991), pulmonary infection (Renom et al. 2007; Wong et al. 2010), and synovitis (Cone et al. 1998; Scholle 2007). It has also been identified as etiologic agent of liver abscesses (Stone et al. 1997) and in mammary gland (Boltin et al. 2009; Martins et al. 2009), keratitis (Heidemann et al. 1991), wounds in skin and surgical (Moore et al. 2010), intrauterine infections (Boltin et al. 2009; Campanile et al. 2009), peritonitis (Bhandari et al. 1995), and in patients affected by AIDS, cancer, and transplanted (Tarr et al. 2003; Martins et al. 2009).

\section{Phenotypic and genotypic typing methods of $C$. striatum}

Corynebacterium spp. are characterized by the presence of arabinose, galactose, meso-diaminopimelic acid, and short chains of mycolic acid in the cell wall; they are aerobic, catalase-positive, not sporulated, and immovable, and can be observed with light microscopy such as irregular Grampositive rods (with pleomorphic cell morphology, presenting coccoid, bacillary, or filamentous forms) (Fig. 1a), individualized or grouped in pairs and/or in the form of palisades (Fig. 1b). Some species can present corynomicolic acids and metachromatic granules as a reserve of high energy phosphate (e.g., C. diphtheriae) (Funke and Bernard 2011).

The identification of $C$. striatum can be performed using the conventional biochemical methods. The biochemical tests used to identify the species mentioned in this work are shown in Table 1. Phenotypic analysis may also be available in semi-automated systems (Camello et al. 2003; Pimenta et al. 2008; Jorgensen et al. 2015).

Nowadays, the identification of bacterial species by mass spectrometry offers quicker and more practical 
Fig. 1 Scanning electron microscopy (SEM). Photomicrograph of adhesion by Corynebacterium striatum to polyurethane catheter surface. Pleomorphism, cells with coccoid, bacillary, and filamentous morphology (a); rods grouped together in a characteristic way "V", "palisades", "Chinese letters" (b); initial adhesion, with the presence of filamentous extracellular material (c); mature biofilm (d). The mechanisms that influence $C$. striatum ability to adhere to different abiotic surfaces and form biofilm remain unknown
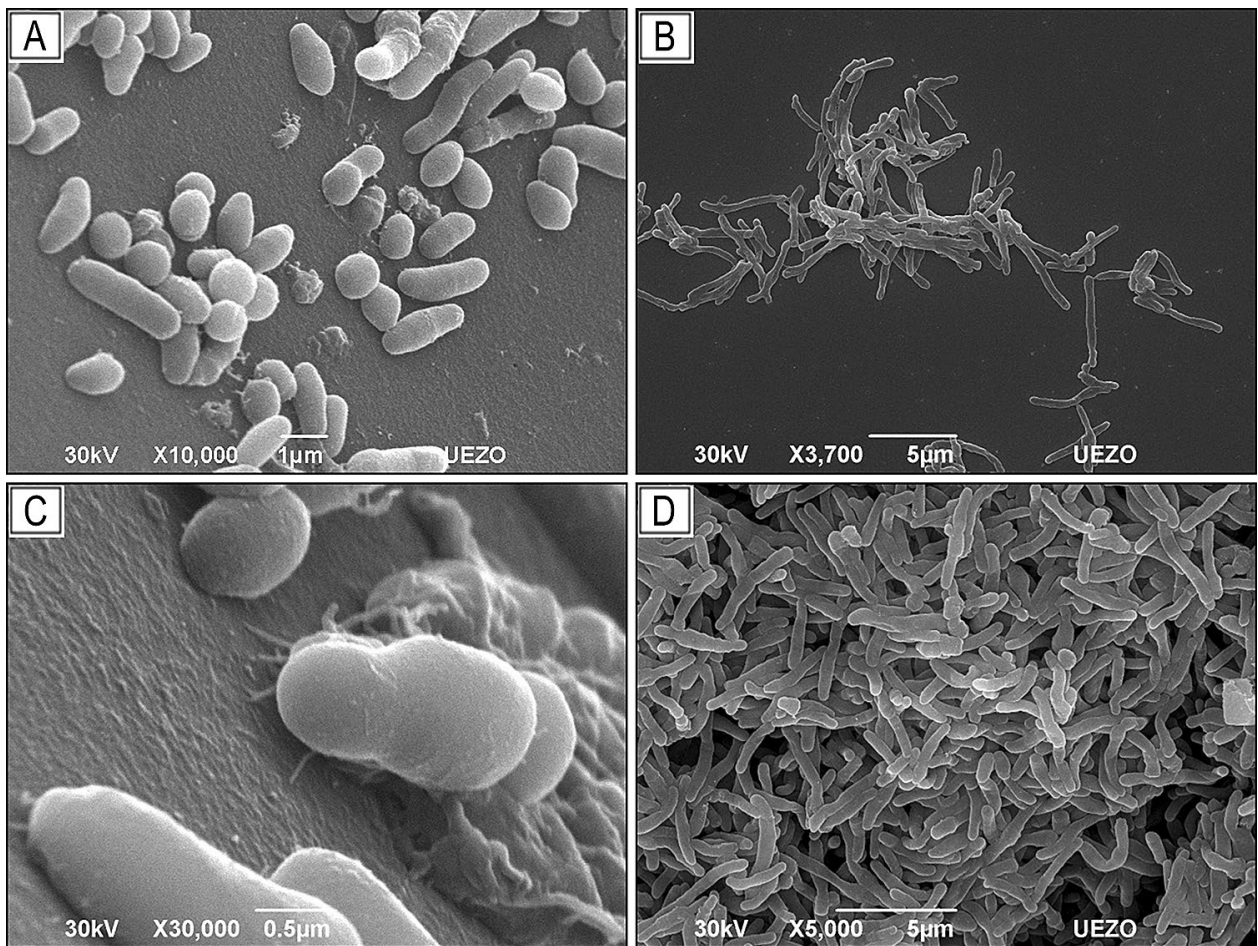

protocols such as the MALDI (Matrix-Assisted Lazer Desorption Ionization), followed by detection in a type analyzer time-of-flight (TOF) and mass spectrometry (MS) (MALDI-TOF MS) (Díez-Aguilar et al. 2013). Molecular methods such as sequencing $16 \mathrm{~S}$ rRNA and rpoB genes are generally used in Reference Laboratories. Molecular technological advances have led to improvements in the survival of immunocompromised patients, as well as in identification, which enabled the increase of case reports in the literature on infections caused by DT-producing and non-DT-producing Corynebacterium species. Genomic analysis may reveal virulence and resistance genes and predominant clones spreading in the hospital environment (Trost et al. 2011; Torres et al. 2013; Wang et al. 2019).

\section{Epidemiological features of $C$. striatum human infections and nosocomial outbreaks}

C. striatum has been increasingly considered as potentially pathogenic microorganism during the last 5 decades. Until the present moment, a review of the available world literature revealed a total of 218 references related $C$. striatum to human infections and nosocomial outbreaks worldwide during the 44-year period of study (https://pubmed.ncbi.nlm. nih.gov). Table 2 and Fig. 2 illustrate the occurrence of a total of 254 cases of $C$. striatum human infections and/or outbreaks from different (Martins et al. 2009) continents and countries, including the first reported case in 1976-United States of America (USA) (Bowstead and Santiago 1980).
Similar to the first case of acute and fatal pulmonary infection, C. striatum infections were associated with underlying medical problems in varied reports. Most cases of $C$. striatum infection occurred in either immunocompromised or damaged skin conditions (Superti et al. 2009; Díez-Aguilar et al. 2013).

Since 2000 C. striatum has been associated with nosocomial infections, mainly in immunodepressed patients, that were hospitalized for long periods in Intensive-Care Units (ICU) due to invasive medical devices such as intravenous catheters. The use of multiple medical devices led to colonization of the upper respiratory tract, with subsequent invasive infection (Martins et al. 2009; Superti et al. 2009; Wong et al. 2010; Díez-Aguilar et al. 2013). During a nosocomial outbreak in Rio de Janeiro metropolitan area, C. striatum predominant genotypes were mostly isolated in pure culture from tracheal aspirates of patients undergoing endotracheal intubation procedures (Baio et al. 2013). Previous studies reported cases of $C$. striatum infection associated to various hospital materials used during respiratory and urological assistance, such as: bronchoscopes, catheters, colonoscopes, laparoscopes, and nasofibroscopes (Scholle 2007; Oliva et al. 2010). Therefore, $C$. striatum should receive special attention, especially when isolated from patients chronically debilitated and/or making use of invasive devices (Renom et al. 2007; Superti et al. 2009; Wong et al. 2010; Baio et al. 2013).

Additionally, C. striatum infections with evolution to bacteremia, recurrence of infection, and/or progression to septic 


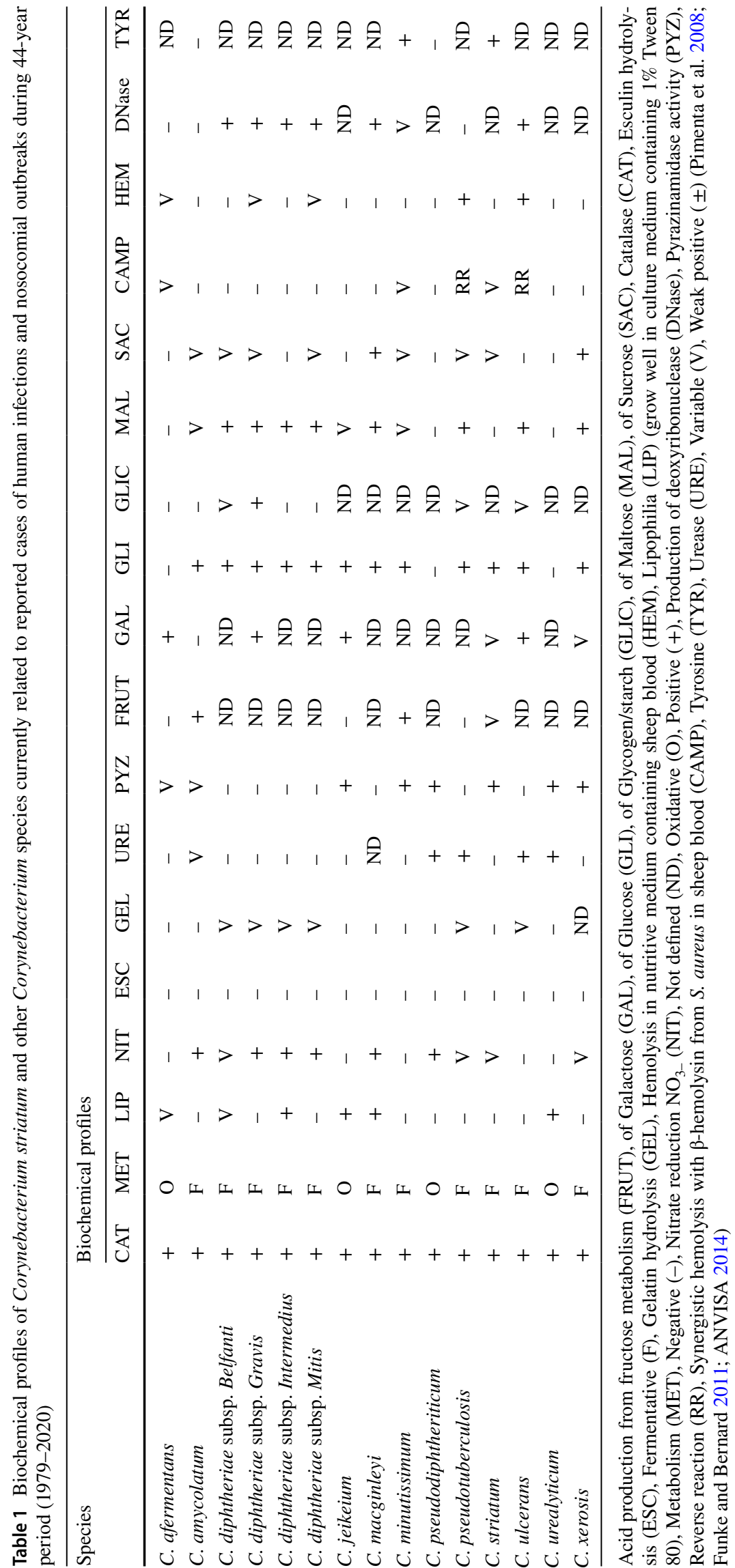




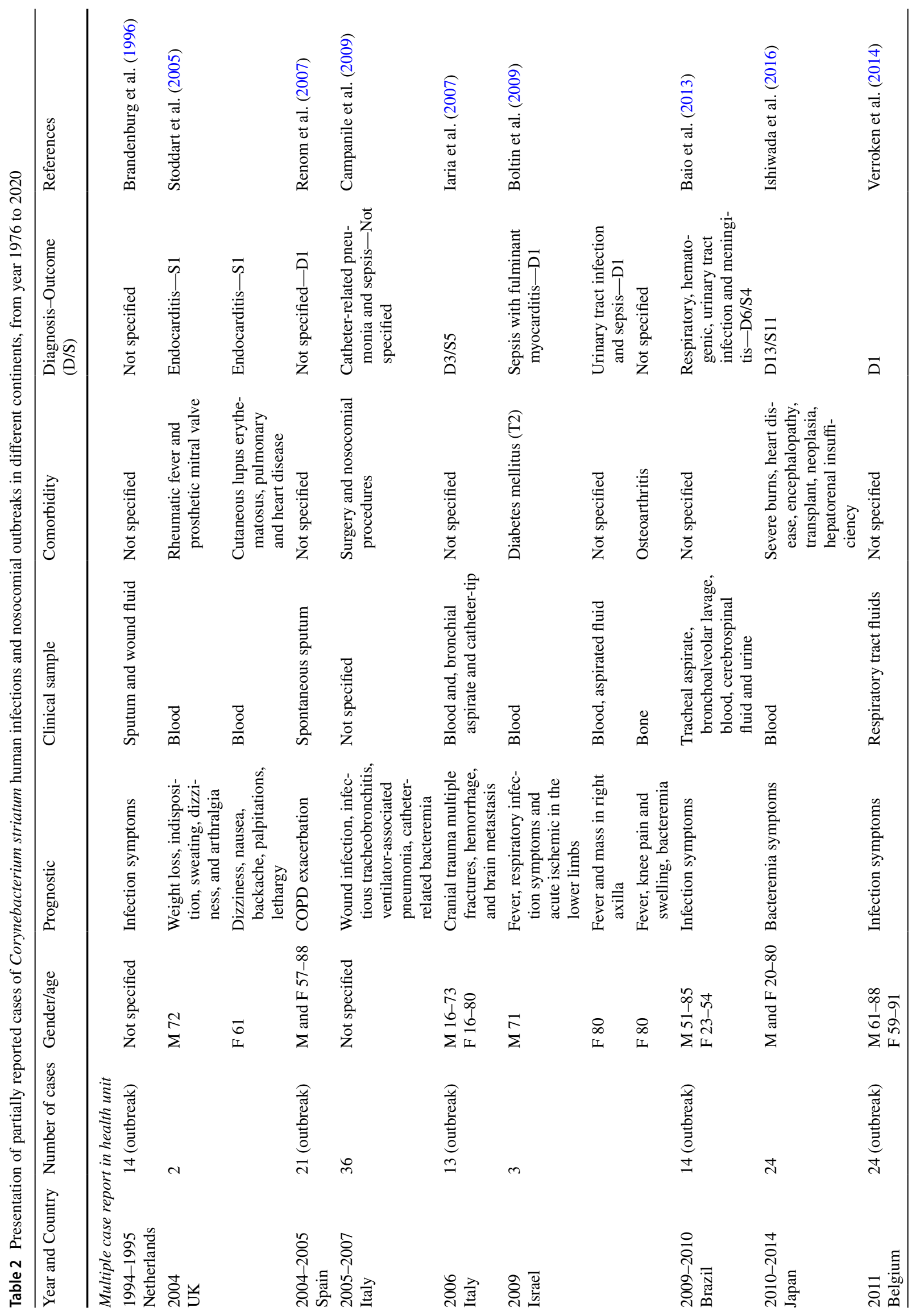




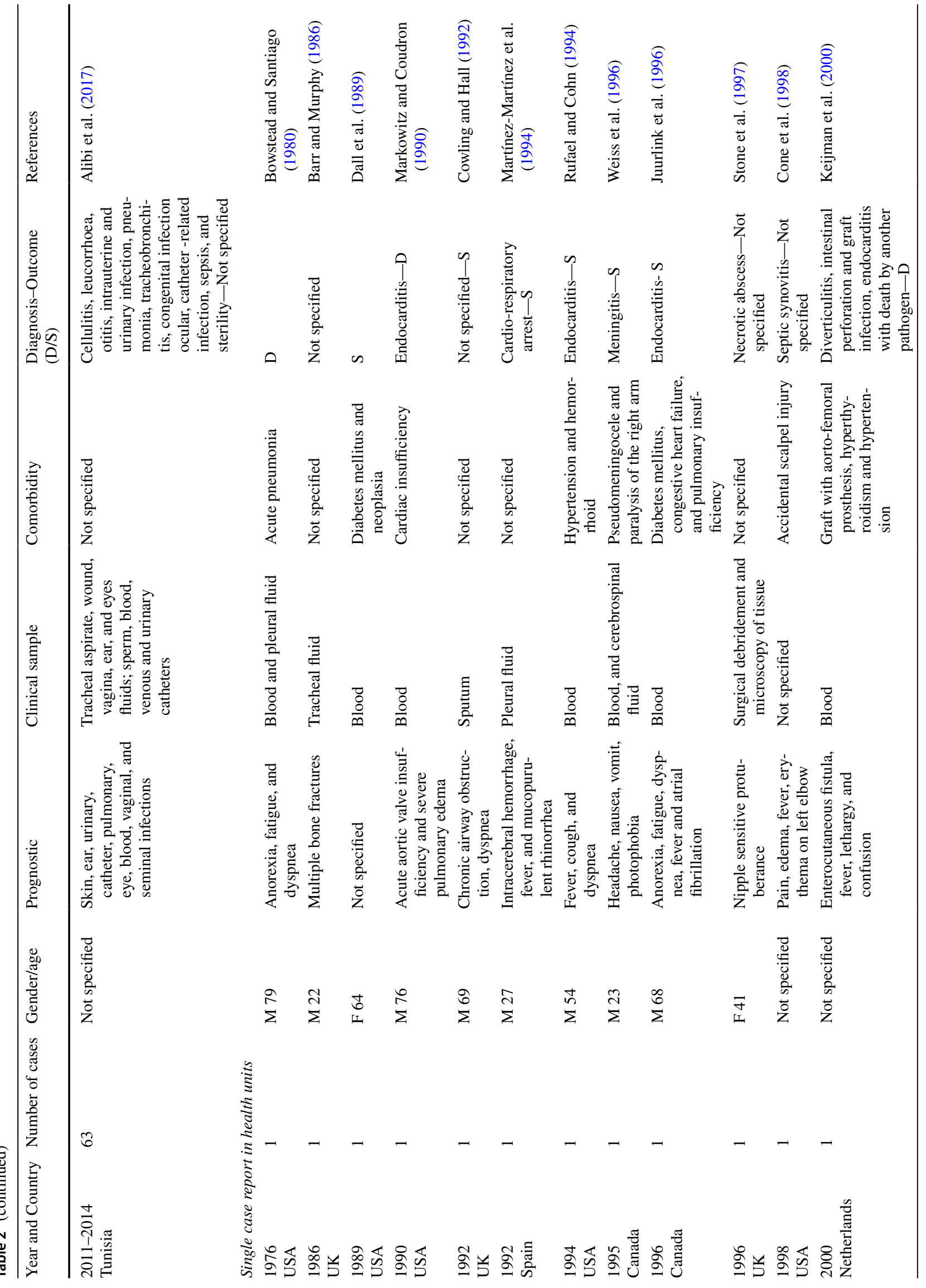




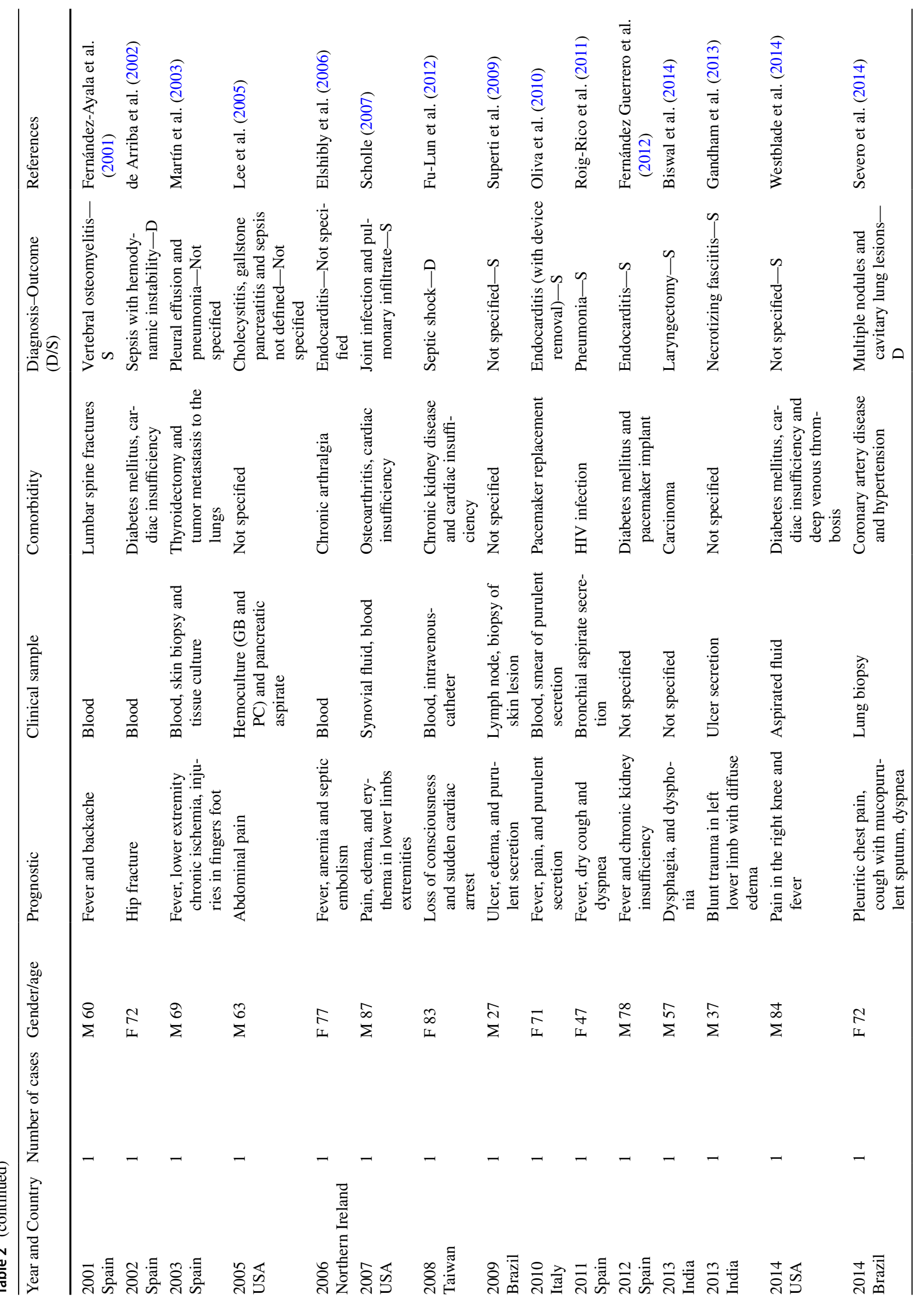




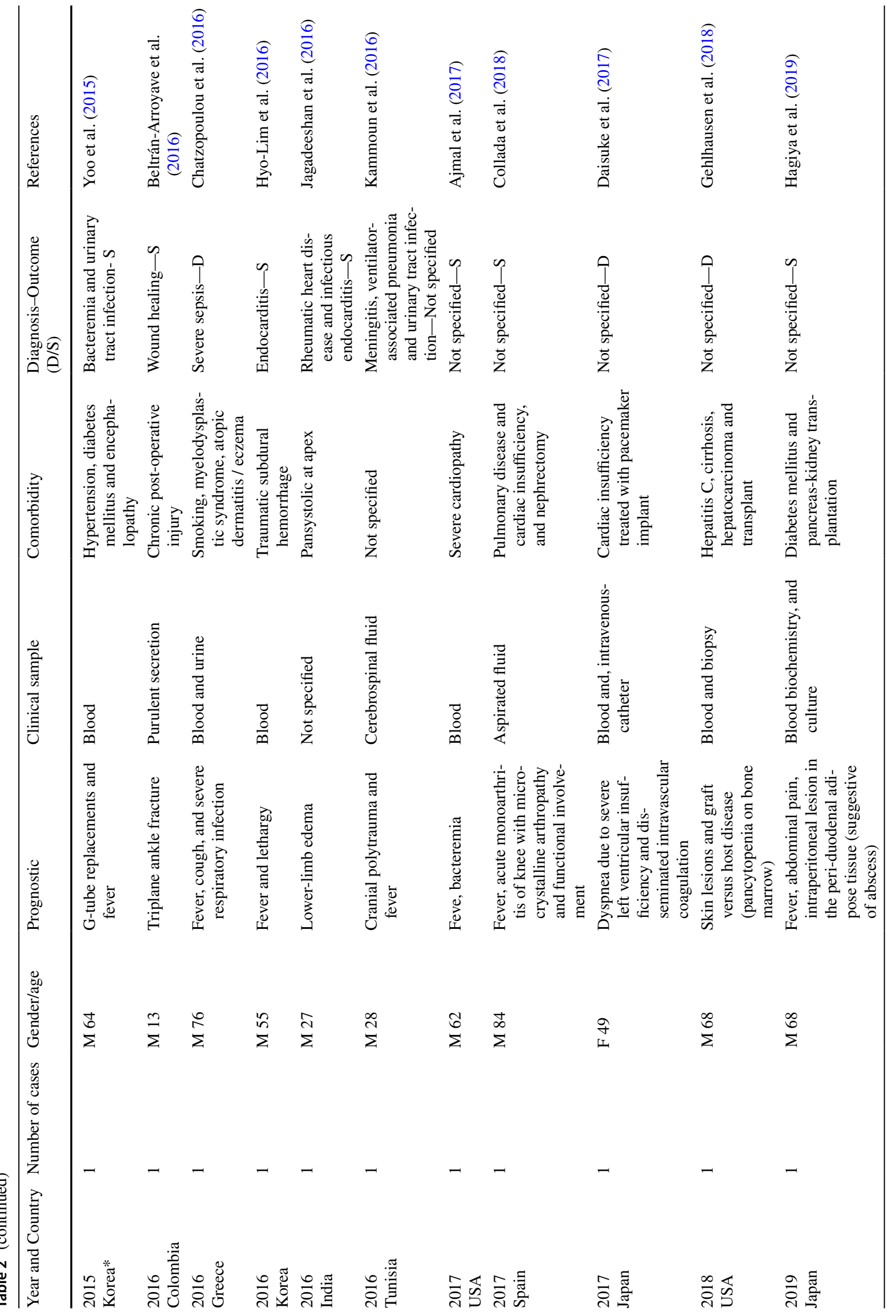


arthritis were also described for pediatric oncology patients from the St Jude Children Research Hospital (Tennessee, USA) (Adderson et al. 2008); the first case of infection in urinary tract by $C$. striatum in outpatient patient, without predisposing factors (López et al. 2009).

\section{Susceptibility to antimicrobial agents}

The incidence antimicrobial-resistant bacterial pathogens isolated from community-acquired or nosocomial infections is a Public Health problem worldwide, including Commissions for Control and Prevention of Hospital Infections in many health institutions, Brazilian Health Regulatory Agency (ANVISA), Centers for Disease Control and Prevention (CDC/USA), and World Health Organization (WHO) (Oliveira et al. 2009).

Antimicrobial resistance has evolved rapidly, leading to therapeutic failure and, consequently, limitations on treatment options; for this reason, the discovery of new drugs with bactericidal properties becomes even more necessary. In the last 40 years, only two drugs were introduced on the market: linezolid and daptomycin (Caumo et al. 2010).

The dissemination of MDR pathogens in hospital environment has been of concern due to increase in rate of acquired resistance to $\beta$-lactam antimicrobials, clindamycin, erythromycin, ciprofloxacin, and gentamycin by Corynebacterium species. Currently, vancomycin, teicoplanin, and linezolid are the most active in vitro drugs against Corynebacterium (Yoon et al. 2011; Reddy et al. 2012). Except for the effective activity of vancomycin against Corynebacterium, the variability in resistance acquisition of other classes of antimicrobials highlights the need for continuous surveillance of resistance profiles in these species (Weiss et al. 1996).

During the last decades that selective pressure exercised by previous treatments with antimicrobials, induced the growth of $C$. striatum as the second most prevalent coryneform microorganism in immunocompromised patients (Adderson et al. 2008; Campanile et al. 2009; Souza et al. 2020). Nevertheless, the criteria for evaluation of susceptibility to antimicrobials for Corynebacterium still are not standardized; some authors suggest that cases of total antibiotic resistance should be reported, that is, absence of any zone (halo) of inhibition in Antimicrobial Susceptibility Test (AST), by the disk-diffusion method in Mueller-Hinton agar medium (MHA), to understand the behavior of different species of this genus under exposure to the drugs in the treatment of infections (Díez-Aguilar et al. 2013). Data emphasize the need for a continuous survey of antibiotic susceptibility for Corynebacterium spp., especially in tropical and developing countries where diphtheria is endemic and invasive infections may occur, as already done for decades in the Brazilian Laboratory of Diphtheria and Corynebacteria 


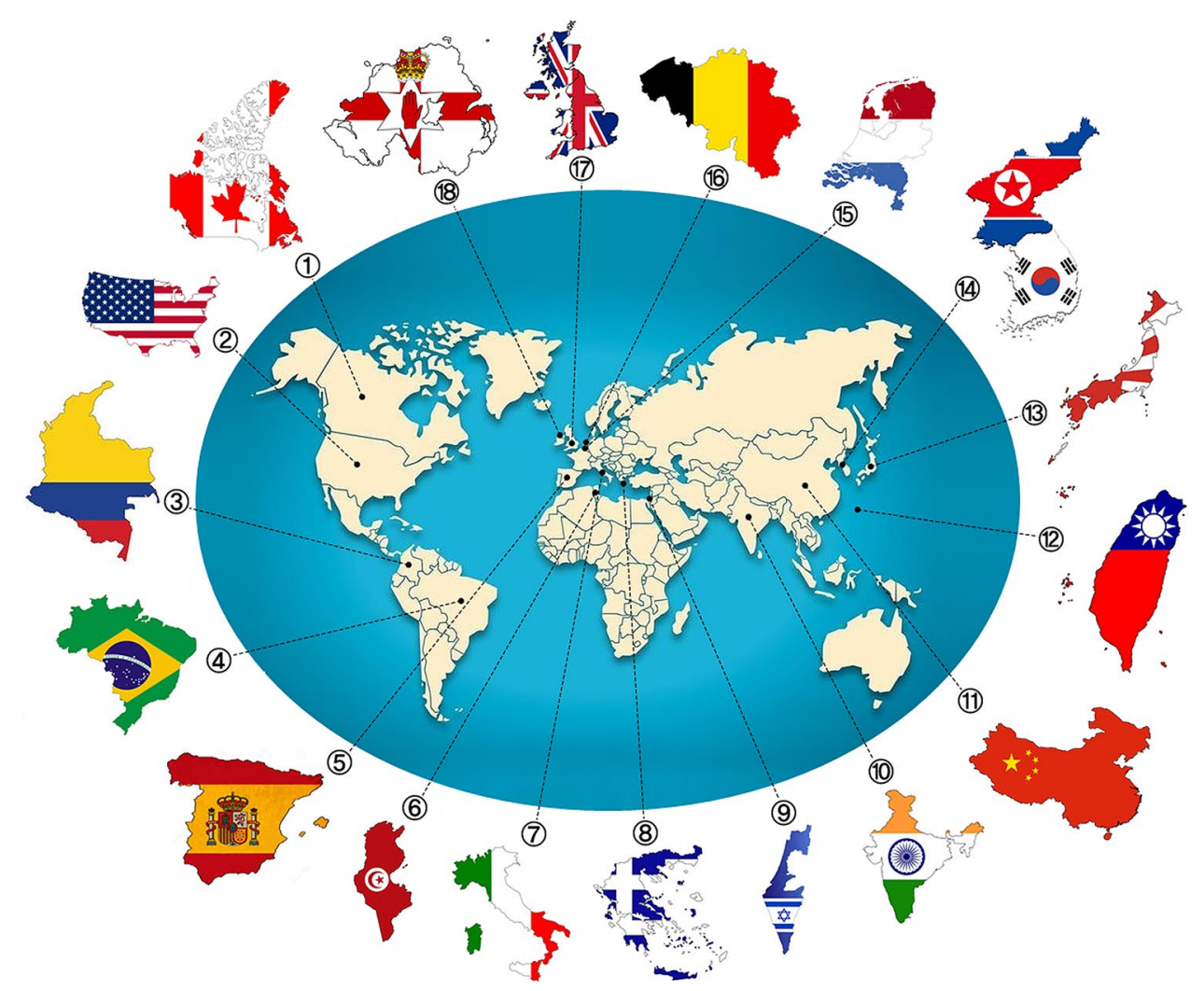

Fig. 2 Worldwide distribution of 254 reported Corynebacterium striatum cases of human infections and/or nosocomial outbreaks from year 1976 to 2020: Canada (1), United States of America (2), Colombia (3), Brazil (4), Netherlands (5), Belgium (6), United Kingdom (7), Northern Ireland (8), Italy (9), Spain (10), Greece (11), Tunisia (12), Israel (13), India (14), China (15), Korea (16), Japan (17), and Taiwan (18). Cases and/or outbreaks were reported in Europe $(n=124)$, Africa $(n=64)$, Asia $(n=36)$, South America $(n=17)$, and

of Clinical Relevance (LDCIC) (Camello et al. 2003; Martins et al. 2009; Baio et al. 2013; Souza et al. 2019).

An increasing number of reports of nosocomial infections due to MDR C. striatum clones have been documented in several countries such as Italy, Spain, The Netherlands, USA, China, and Japan (Adderson et al. 2008; Boltin et al. 2009; Campanile et al. 2009; Wong et al. 2010). However, in developing countries, including Latin America, notifications MDR C. striatum infections remain occasional, possibly due to the need for qualified professionals in performing accurate isolation and identification of slow-growing Gram-positive irregular rods microorganisms. Additionally, the requirement of many phenotypic tests and the necessity of costly, sophisticated procedures make it difficult or even impossible to identify coryneform species in laboratories with scarcity of resources (Camello et al. 2003; Pimenta et al. 2008; Superti et al. 2009; Torres et al. 2013).

In Japan, C. striatum strains demonstrated variable susceptibility rates to $\beta$-lactams and aminoglycosides, in addition to high levels of resistance for erythromycin,
North America $(n=13)$. Nosocomial outbreaks were reported in Belgium $(n=24)$, Spain $(n=21)$, Brazil $(n=14)$, Netherlands $(n=14)$, and Italy $(n=13)$. Multiple and single cases were reported in health units China $(n=1)$, Colombia $(n=1)$, Greece $(n=1)$, Netherlands $(n=1)$, Northern Ireland $(n=1)$, Taiwan $(n=1)$, Brazil $(n=2)$, Canada $(n=2)$, Korea $(n=2)$, India $(n=3)$, Israel $(n=3)$, United Kingdom $(n=5)$; Spain $(n=7)$; United States $(n=11)$; Japan $(n=26)$; Italy $(n=37)$, and Tunisia $(n=64)$

tetracycline, rifampicin, and ciprofloxacin, and $100 \%$ susceptibility to vancomycin. Pulsed-field Gel Electrophoresis (PFGE) analysis of $C$. striatum characterized 14 pulsotypes $\mathrm{A}, \mathrm{D}$, and $\mathrm{E}$ PFGE types associated with nosocomial outbreaks of respiratory origin and subtypes A1, A2, D2, and E with resistance to a wide variety of antimicrobial agents (Otsuka et al. 2006). In Spain, all C. striatum strains isolated from nosocomial outbreaks showed resistance to three or more antimicrobials from different classes and were described as MDR, of which $65 \%$ were resistant to four or five classes of antibiotics; $6.9 \%$ susceptible only to imipenem and vancomycin and $11 \%$ susceptible only to vancomycin (Renom et al. 2007).

In South America, cases of $C$. striatum infections and nosocomial outbreaks were only reported in Brazil. C. striatum strains were isolated from different colonization sites, including the upper and lower respiratory tract, and surgical wounds of cancer patients from a reference center located in Rio de Janeiro (Martins et al. 2009). In 2009, C. striatum strains also triggered an outbreak in a care hospital located at 
the Rio de Janeiro metropolitan area, Brazil; where C. striatum strains were isolated in ICUs and surgical wards, mainly from tracheal aspirates of patients undergoing endotracheal intubation procedures and were mostly MDR. About $87 \%$ of the strains belonged to PFGE-types I and II and were related to the death of five infected patients. Surprisingly, only adult patients were colonized by MDR C. striatum strains and 50\% had age higher than 50 years. Infections by these MDR $C$. striatum clones were frighteningly correlated to death (Baio et al. 2013).

There is still limited database available for $C$. striatum, such as PulseNet (http://www.cdc.gov/pulsenet) that allows the comparison of standards of PFGE observed in different nosocomial outbreaks in different countries. Studies performed during a nosocomial outbreak in Italy evidenced profiles such as SwaI-PFGE with band size varying between 48.5 and $533.5 \mathrm{~kb}$ (Campanile et al. 2009). In Brazil, MDR C. striatum strains isolated during an outbreak expressed PFGE-profiles such as SwaI-PFGE of $C$. striatum with band size varying between 97.0 and $533.5 \mathrm{~kb}$ (Baio et al. 2013). Comparative analysis between the Italian and Brazilian outbreaks revealed the absence of band sizes suggesting differences among MDR strains (Campanile et al. 2009; Baio et al. 2013). Moreover, phenotypic analysis of MDR C. striatum strains isolated during outbreaks in Brazil and in The Netherlands were found to express different biotypes: nitrate/ pyz-positive and sucrose-negative, respectively (Brandenburg et al. 1996). The mechanisms of resistance to antimicrobial agents and tolerance to antiseptic and disinfectants of $C$. striatum strains need further investigation; however, it is known that the low-permeability external wall, the great lipid content, and the capacity of forming biofilm can contribute to tolerance to various antimicrobial agents (Souza et al. 2019, 2020).

\section{Control of $C$. striatum dissemination in hospital environment}

Hospital infections are of epidemiological relevance in both nosocomial and Public Health assistance due to raise in morbimortality rates, and increase time of permanence of patients in hospitals, with irreparable economically and socially consequences. Usually, higher index of infection occurs in ICUs than in the other hospital areas, partially due to immunodeficiency conditions of patients and interaction with pathogens present in contaminated surfaces (ANVISA 2000). There is a worldwide concern with control nosocomial environmental conditions due to recurrent outbreak and varied types of infections caused by MDR pathogenic species. Control of nosocomial outbreaks require cautious environmental decontamination mainly dependent of specific routines procedures and particular technical training. Moreover, antimicrobial therapies with a rational use of antibiotics of hospitalized patients with infectious diseases should be also taken into consideration (ANVISA 2004, 2014). Hospital Infection Control Commission (HICC) is responsible for standardization of routine and protocols with employee training, selection of chemical decontaminating agents, application of updated techniques of cleaning, decontamination, and disinfection, with the constant evaluation of the effectiveness of antimicrobial agents via Brazilian standardized protocols. Clinical invasive procedures performed in children and adult's attendance in nosocomial units, especially in critical sectors, may contribute to Infections Related to Health Care (IRHC), including surgical treatment and insertion of medical-invasive devices (ANVISA 2004, 2014).

Despite advanced sterilization and asepsis techniques, hospital-acquired infection due to invasive procedures remain a problem, partially due to enhancement of resistance to antimicrobial agents of bacterial pathogens (Renom et al. 2007). Constant reports of transmission of infectious agents during invasive procedures are arising from inefficiency in cleaning and disinfecting surgical environments, but mainly from inappropriate decontamination of hospital materials (Howie et al. 2008). Several chemical agents have been in used to control bacterial growth in hospital environments, both in the presence as well as in the absence of organic matter. However, the choice of the appropriate chemical agents for each different type of disinfection as well as the disinfection method used for each type of surface is essential to obtain a controlled hospital environment with minimal risk of infections (Rutala and Weber 2008; Vermelho et al. 2008).

Glutaraldehyde (GA) stands out for its broad spectrum, among the components that can be used as disinfectants in the hospital environment, acting against Gram-positive and Gram-negative pathogens, mycobacteria (especially, Mycobacterium tuberculosis), as well as some viruses, fungi, and their spores that can cause hospital infections. The microbicidal activity of this agent comes from the alkylation of sulfhydryl, hydroxyl, carboxyl, and amino groups of microorganisms, changing DNA, RNA, and protein synthesis, with consequent inhibitory action on transport and enzyme systems, where the access of the substrate to the enzyme is compromised. Sporicidal activity of glutaraldehyde is related to interaction with the spore surface, provoking the hardening of external layers. In many hospitals, non-corrosive glutaraldehyde $2 \%$ solution at $\mathrm{pH} 8.0$ (activated glutaraldehyde/alkaline), has been used to disinfect materials with surgical purposes in critical and semi-critical environments, but cannot be subjected to heat (rubber and plastic). Unfortunately, the use is limited high-level disinfection due to glutaraldehyde toxicity (Lorena et al. 2009).

Peracetic acid has been suggested as an alternative to replace glutaraldehyde in disinfection of materials in critical 
and semi-critical environments, for its effectiveness against several pathogens, as well as its bactericidal, tuberculicidal, virucidal, fungicidal, and sporicidal action, even in the presence of organic matter, Peracetic acid has high oxidizing power in cellular components, acting on the cytoplasmic membrane and deactivating the physiological functions, including the osmotic barrier. However, some disadvantages include reduced time of action post-dilution (a solution at $1 \%$ loses activity in 6 days by hydrolysis or oxidation in the presence of iron and copper), low stability in stock, and the need for specialized handling, due to its corrosive activity that can cause skin irritation (Block 2001; Sattar and Springthorpe 2001; McDonnell 2007).

Sodium hypochlorite $(\mathrm{NaClO})$ use is limited to abiotic surfaces and other materials that do not come into direct contact with the patient due to a high corrosive power. $\mathrm{NaClO}$ is a salt of hypochlorous acid, in equilibrium with the hypochlorite anion that has high oxidizing power due to the neutral charge and diffuses easily through the cell wall of bacteria (Andrade 1988).

Potassium monopersulfate is a new chemical agent, which acts through oxidizing sulfhydryl groups present in proteins, thus eliminating microorganisms. The most important characteristic is the activity in the presence of organic matter, besides not being corrosive to metals. However, it has been more used in materials in the non-critical environment (medical office, pharmacy; that is, where there is no risk of transmission of infection as well as no patients), due its low effectiveness in mycobacteria, the loss of activity after 7 days of activation, the necessity of technically qualified professionals for dilution maintaining their color, as reduction of intensity in color means decreased effectiveness (Rutala et al. 1996; Silva et al. 2013).

The ortho-phthalaldehyde was initially considered a high-level disinfectant by the Food and Drug Administration (FDA), for interacting with proteins and amino acids of microorganisms. The benefits when compared with glutaraldehyde includes toxicity, odor, and good stability in $\mathrm{pH} \sim 3.0-9.0$, not causing irritation to the eyes nor to the airways and it is non-teratogenic and non-mutagenic nature. However, it has the disadvantages of staining the skin, mucosa, and other surfaces exposed to the environment, as well as causing hypersensitivity in patients with repeated exposure and having a higher cost than glutaraldehyde, while having low sporicidal activity (Psaltikidis et al. 2014).

The glucoprotamine comes from a conversion reaction of the amino acid L-glutamic acid with cocosamine, a substance extracted from the coconut. Although the mechanism of action remains unclear, the effectiveness is proven, and correlation with the oxidation of vital substances of microorganisms is a possibility. Glucoprotamine has ecologically important advantages, since it is biodegradable and its disposal does not damage the environment, making neutralization unneeded. Moreover, glucoprotamine presents a high spectrum of action against microorganisms, a noncorrosive activity in addition to affinity with most metals, such as stainless steel, brass, aluminum, and others (Widmer and Frei 2003).

Only a few studies were found available in the literature concerning the effects of biocidal agents in Corynebacterium spp. pathogens. Corynebacterium species are included among as the most resistant pathogenic species expressing resistance during analysis of efficiency of disinfection protocols used in health care instruments and environments, especially $C$. striatum and $C$. amycolatum. Previous research detected Corynebacterium species after gastrointestinal endoscopes submitted to disinfection with $2 \%$ peracetic acid or $2 \%$ glutaraldehyde solutions, during periods of exposure up to $30 \mathrm{~min}$. Comparative analysis among different biocidal agents showed in vitro microbicidal activity of $5 \%$ povidone iodine, $4 \%$ chlorhexidine digluconate and $0.01 \%$ hypochlorous acid solutions for $C$. striatum and $C$. amycolatum strains, indicating efficiency in preoperative antisepsis (Anagnostopoulos et al. 2018). Chlorhexidine $0.05-0.5 \%$ solutions have been used as a skin cleanser for surgical scrubs, as a cleanser for skin wounds, for preoperative skin preparation, germicidal hand rinses, ocular conjunctiva, and varied mucosal surfaces, in addition to treatment of umbilical cord. Recently, a comparative analysis of disinfection efficiency between two associations of biocides $(0.5 \%$ chlorhexidine and $70 \%$ ethyl alcohol versus $1 \%$ iodine and $70 \%$ ethyl alcohol solutions) used in orthopedic surgeries, showed that Corynebacterium pathogenic species were included among the group microorganisms mostly isolated from skin surface after surgical procedure (Shadid et al. 2019). Therefore, treatment with chlorhexidine during preoperative procedures led to a significant inhibition of Corynebacterium spp. growth condition; however, it did not exert microbicidal effect on biotic (skin) surfaces in vivo, as expected (Gili et al. 2018).

Nowadays, infections related to health services (HAIs) due to MDR and multidrug-susceptible (MDS) C. striatum should not be underestimated, including patients using invasive medical devices. Disinfection and antisepsis are of primary importance in controlling nosocomial infections and outbreaks by pathogens expressing multiple resistance to antimicrobial agents used in therapy. Several studies reported the efficacy of disinfectants and antiseptics agents and correlation with technical procedures mostly on abiotic surfaces. Phenotypic and genotypic properties of microorganisms, including mechanisms of survival and resistance to antimicrobial agents, should be also a matter of concern, considering the efficacy of disinfectants and antiseptics agents. A recent study verified the ability of biofilm formation by $C$. striatum strains on abiotic substrates, including steel surfaces, and survival of sessile forms in the presence 
of GA. Moreover, bovine serum albumin (BSA), organic substance, increased the survival of planktonic and sessile forms in the presence of GA. Data demonstrated that hospital staff should be aware of dissemination and eradication of HAIs by $C$. striatum presenting resistance to biocides, including high-level disinfectants, such as GA (Souza et al. 2020).

The presence of organic matter is related to the ineffectiveness of chemical agents, as some agents have reduced action in the presence of carbon chains. Assessing the influence of organic matter on the disinfection process is important, as the materials from the critical and semi-critical environments are in direct contact with organic substances such as pus, blood, serum, and others (Lewis and Arens 1995). Mechanical cleaning with soap and water, performed manually with a brush and individual protection equipment (IPE), aims to remove all organic material, and reduce the presence of microorganisms in surgical materials, so that there is no interference in antimicrobial activity of disinfectants, or does not lead to the formation a physical barrier of protection to microorganisms during disinfection and sterilization processes by physical and chemical means. The meticulous cleaning of surgical materials, before submitting them to disinfection or sterilization, is a unanimous and universal procedure (Souza et al. 1998). The cell wall of Gram-positive bacteria has a high concentration of several biochemical compounds such as lipopolysaccharide (LPS), lipids with a very intense hydrophobic profile, granting the favorable properties of tolerance to hydrophilic chemical agents and of adhesiveness to hydrophobic surfaces. Adhesion and persistence mechanisms presented by microorganisms, especially under stress conditions, such as adhesins and invasins, enzymes are also capable of neutralizing the oxidizing action and sequestering micronutrients and the ability to produce biofilm that collaborate to resist the action of biocidal agents (Costerton et al. 1999). In addition, other factors may also change the action of chemical agents in disinfection processes, such as the acquisition of resistance genes through genetic transfer, mechanisms of pumping chemical substances out of the bacterial cytoplasm (efflux pumps), high-molecular-weight proteins found in the outer membrane of bacteria (porin channels) (Costerton et al. 2003). Deficiencies in the purine channels (proteins exposed on the surfaces of the bacterial cell, which usually transport molecules like antibiotics and disinfectants to the cell interior) can also represent a mechanism of tolerance to chemical agents especially to aldehyde-based agents, like glutaraldehyde and ortho-phthalaldehyde (Svetlíková et al. 2009).

The increased recognition of the pathogenic potential of $C$. striatum by health professionals and researchers, and investigations of virulence and multidrug-resistance mechanisms have been currently considered (Oliva et al. 2010; Díez-Aguilar et al. 2013; Ramos et al. 2019; Souza et al.
2019, 2020). Recent publications reveal the ability of $C$. striatum to adhere to various abiotic surfaces and to form biofilms in catheter models in vitro, allowing for an association between the increase in biofilm formation, multiresistance antibacterial, and clonality of strains. The clinical isolates of different types of PFGE expressed a high capacity to form biofilms on hydrophilic abiotic surfaces (glass; positive charge) and hydrophobic (polystyrene; negative charge), including polyurethane catheter surfaces (positive charge). Nowadays, dissemination among patients through contaminated hands of health professionals, abiotic surfaces, and invasive medical procedures is a matter of concern (Moore et al. 2010; Díez-Aguilar et al. 2013; Souza et al. 2015, 2020) (Fig. 1c, d). However, little is known about its virulence factors that can contribute for Health Care Related Infections (HCRI) (Souza et al. 2015; Ramos et al. 2019). Relevant contributing factors to $C$. striatum hospital infections, include resistance gene transfer, inappropriate, and irrational use of antimicrobials promoting the selection of resistant bacteria, inefficiency in cleaning, and decontamination of hospital surfaces and materials used in critical areas (such as the surgical and sterilization center, hemodialysis, lactation, burn treatment, mortuary, laboratory and expurgation) and semi-critical (wards, rooms, ambulances, and ambulatories) (Rutala et al. 1996; Vermelho et al. 2008).

\section{Discussion}

MDR strains have been a concern among epidemiologists and the entire medical community, due to being isolated both in the hospital environment and in the community (Santos 2004; ANVISA 2007). The search for strategies to reduce the dissemination of HCRI is currently a worldwide concern (Santos 2004; ANVISA 2007). The mechanisms involved in antimicrobial resistance are increasingly well understood. Resistance can be a natural property of a microorganism (intrinsic), or acquired by mutation, acquisition of plasmids, and transposons. Studies related to the development of multi-resistance in $C$. striatum have focused on the presence of genes of resistance, such as $\operatorname{erm}(\mathrm{X})$, encoding resistance to erythromycin and clindamycin, tet $A$ and $\operatorname{tet} B$, encoding resistance to tetracycline, oxytetracycline, and oxacillin, $c m x$ and $a p h A l$, encoding resistance to aminoglycosides and chloramphenicol (Campanile et al. 2009). Many measures are being taken in Brazil to control the rise of MDR strains of $C$. striatum (Santos 2004; ANVISA 2007). There are many promises for the development of new antimicrobials and disinfection products for medical-surgical materials. However, many barriers must be overcome, as the benefits of implementing a new drug should outweigh the disadvantages. New studies have sought to investigate therapeutic alternatives 
for infections caused by multi-resistant bacteria, like synergistic combinations of two or more antibiotics, increasing the effectiveness and decreasing toxicity of the medication (Soares 2001; Mitsugui et al. 2008).

Disinfectants and antiseptics are used extensively in hospitals and other healthcare institutions for a variety of topical applications and on various surfaces. They are an essential part of infection control practices and help prevent nosocomial infections. The widespread use of antiseptic and disinfectant products has led to some investigations on the development of microbial resistance, particularly a cross-resistance for antibiotics. Antimicrobial activity can be influenced by many factors, such as chemical formulation, presence of organic waste, temperature, drug dilution, and decontamination method (Rutala and Weber 2008; Vermelho et al. 2008). Biocides when properly used and in conjunction to other procedures in infection control are essential in combating HCRI and eradicating MDR microorganisms. If management is inefficient, improper use of biocides during cleaning processes in the hospital environment can contribute to the persistence and dissemination of opportunistic pathogens, both in hospitals and in the community (McDonnell and Russell 1999).

Therefore, C. striatum strains have been increasingly verified as a nosocomial pathogen of severe infections and outbreaks in different continents, but mostly in industrialized countries. Multidrug-resistant $C$. striatum clones may be related to varied types of infections, especially in longterm hospitalized patients with prolonged exposure to broadspectrum antibiotics and admitted in ICU or surgical wards using continuous or prolonged medical devices and respiratory recuperation, including patients with advanced chronic respiratory disease (mainly among elderly male patients). C. striatum strains may be transmitted between patients, from person to person and via caretakers. Clinical bacteriology laboratories, $C$. striatum strains are still discarded as contaminants, including when isolated from blood samples. Considering MDR nosocomial C. striatum strains as contaminant is a serious error, especially when isolated from chronically impaired patients using invasive devices (Superti et al. 2009; Wong et al. 2010; Baio et al. 2013; Díez-Aguilar et al. 2013; Savini et al. 2013).

\section{Future prospects}

Reliable laboratory diagnosis and appropriate actions to control $C$. striatum environmental dispersion are required. Further studies remain necessary to investigate clinical, epidemiological, and microbiological features concerning $C$. striatum infections to prevent future problems and guarantee continued vigilance by laboratories and medical community.

\section{Significance and impact of the study}

In this investigation, C. striatum was described as a potentially multidrug-resistant (MDR) pathogenic microorganism that causes healthcare-associated infections (HAIs) and nosocomial outbreaks. Cases of severe invasive infections occur especially among immunocompromised patients who have experienced long hospital admissions, several courses of antibiotics, and/or those who made use of invasive medical devices. The present study reinforces increasing participation of $C$. striatum as etiologic agent of human diseases, in addition to accurate clinical and laboratorial diagnosis and antimicrobial susceptibility testing of Corynebacterium species by health professionals to prevent death of immunodeficient and immunocompetent patients.

Acknowledgements We would like to thank Institute of Microbiology Professor Paulo de Góes/UFRJ, Laboratory of Diphtheria and Corynebacteria of Clinical Relevance/UERJ.

Author contributions All authors have substantially contributed to the conception, design, acquisition, and analysis of data. Moreover, there was partnership in drafting and critical revision of the manuscript as well as the approval of the final submitted version.

Funding This study was funded in part by the National Council for Scientific and Technological Development (CNPq), Coordination for the Improvement of Higher Education Personnel—Brazil (CAPES) Finance Code 001, and Research Support Foundation for the State of Rio de Janeiro-Brazil (FAPERJ).

\section{Declarations}

Conflict of interest The authors declare that they have no conflict of interest.

\section{References}

Adderson EE, Boudreaux JW, Hayden RT (2008) Infections caused by coryneform bacteria in pediatric oncology patients. Pediatr Infect Dis J 27:136-141. https://doi.org/10.1097/INF.0b013 e31814fab12

Agência Nacional de Vigilância Sanitária (ANVISA) (2000) Curso Básico de Controle de Infecção Hospitalar. In: Caderno C Métodos de proteção anti-infecciosa. p 84. Rio de Janeiro. http:// www.cvs.saude.sp.gov.br/pdf/CIHCadernoC.pdf. Accessed 2 Dec 2018

Agência Nacional de Vigilância Sanitária (ANVISA) (2004) Anvisa enhances infection control in health services. Rev Saúde Pública 38:475-478. https://doi.org/10.1590/s0034-89102004000300022

Agência Nacional de Vigilância Sanitária (ANVISA) (2007) Controle de Infecção em Serviços da Saúde. Rio de Janeiro. http://www. anvisa.gov.br/servicosaude/controle/reniss/manual\%20_contr ole_bacterias.pdf. Accessed 15 Feb 2018

Agência Nacional de Vigilância Sanitária (ANVISA) (2014) Controle de Infecção em Serviços da Saúde. Rio de Janeiro. http://www. 
anvisa.gov.br/servicosaude/controle/legis.htm. Accessed 4 Jan 2018

Ajmal S, Saleh OA, Beam E (2017) Development of high-grade daptomycin resistance in a patient being treated for Corynebacterium striatum infection. Antimicrob Agents Chemother 61:e00705e00717. https://doi.org/10.1128/AAC.00705-17

Alibi S, Ferjani A, Boukadida J, Cano ME, Fernández-Martínez M, Martínez-Martínez L, Navas J (2017) Occurrence of Corynebacterium striatum as an emerging antibiotic-resistant nosocomial pathogen in a Tunisian hospital. Sci Rep 7:9704. https://doi. org/10.1038/s41598-017-10081-y

Anagnostopoulos AG, Rong A, Miller D, Tran AQ, Head T, Lee MC, Lee WW (2018) $0.01 \%$ hypochlorous acid as an alternative skin antiseptic: an in vitro comparison. Dermatol Surg 44:1489-1493. https://doi.org/10.1097/DSS.0000000000001594

Andrade NJ (1988) O uso de compostos clorados na indústria de laticínios. Inf Agropec Belo Horizonte 13:48-52

Azevedo Antunes C, Richardson EJ, Quick J, Fuentes-Utrilla P, Isom GL, Goodall EC, Möller J, Hoskisson PA, Mattos-Guaraldi AL, Cunningham AF, Loman NJ, Sangal V, Burkovski A, Henderson IR (2018) Complete closed genome sequence of nontoxigenic invasive Corynebacterium diphtheriae bv mitis strain ISS 3319. Genome Announc 6:e01566-e1617. https://doi.org/10.1128/ genomeA.01566-17

Baio PVP, Mota HF, Freitas AD, Gomes DLR, Ramos JN, Sant'Anna LO, Souza MC, Camello TCF, Hirata Junior R, Vieira VV, Mattos-Guaraldi AL (2013) Clonal multidrug-resistant Corynebacterium striatum within a nosocomial environment, Rio de Janeiro, Brazil. Mem Inst Oswaldo Cruz 108:63-98. https://doi. org/10.1590/S0074-02762013000100004

Barr JG, Murphy PG (1986) Corynebacterium striatum: an unusual organism isolated in pure culture from sputum. J Infect 13:297298. https://doi.org/10.1016/s0163-4453(86)91454-4

Beltrán-Arroyave C, Díaz-Díaz A, Loaiza-Díaz N (2016) Chronic osteomyelitis due to Corynebacterium striatum in a female adolescent. Rev Chil Infectol 33:696-699. https://doi.org/10.4067/ S0716-10182016000600014

Bernard K, Pacheco AL, Cunningham I, Gill N, Burdz T, Wiebe D (2013) Emendation of the description of the species Corynebacterium propinquum to include strains which produce urease. Int J Syst Evol Microbiol 63:2146-2154. https://doi.org/10.1099/ ijs.0.046979-0

Bhandari S, Meigh JA, Sellars L (1995) CAPD peritonitis due to Corynebacterium striatum. Perit Dial Int 15:88-89. https://doi. org/10.1177/089686089501500126

Biswal I, Mohapatra S, Deb M, Dawar R, Gaind R (2014) Corynebacterium striatum: an emerging nosocomial pathogen in a case of laryngeal carcinoma. Indian J Med Microbiol 32:323-324. https ://doi.org/10.4103/0255-0857.136589

Block SS (2001) Peroxygen compounds. In: Block SS (ed) Disinfection, sterilization, and preservation. Lipp. Wil \& Wil, Philadelphia, pp 185-204

Boltin D, Katzir M, Bugoslavsky V, Yalashvili I, Brosh-Nissimov T, Fried M, Elkayam O (2009) Corynebacterium striatum-a classic pathogen eluding diagnosis. Eur J Intern Med 20:e49-e52. https ://doi.org/10.1016/j.ejim.2008.08.009

Bowstead TT, Santiago SM (1980) Pleuropulmonary infection due to Corynebacterium striatum. Br J Dis Chest 74:198-200. https:// doi.org/10.1016/0007-0971(80)90035-2

Brandenburg AH, van Belkum A, van Pelt C, Bruining HA, Mouton JW, Verbrugh HA (1996) Patient-to-patient spread of a single strain of Corynebacterium striatum causing infections in a surgical intensive care unit. J Clin Microb 34:2089-2094. https://doi. org/10.1128/JCM.34.9.2089-2094.1996

Camello TCF, Mattos-Guaraldi AL, Formiga LCD, Marques EA (2003) Nondiphtherial Corynebacterium species isolated from clinical specimens of patients in a university hospital, Rio de Janeiro, Brazil. Braz J Microbiol 34:39-44. https://doi.org/10.1590/ S1517-83822003000100009

Campanile F, Carretto E, Barbarini D, Grigis A, Falcone M, Goglio A, Venditti M, Stefani S (2009) Clonal multidrug-resistant Corynebacterium striatum strains, Italy. Emerg Infect Dis 15:7578. https://doi.org/10.3201/eid1501.080804

Carvalho RV, Lima FFDS, Santos CSD, Souza MC, Silva RSD, Mattos-Guaraldi AL (2018) Central venous catheter-related infections caused by Corynebacterium amycolatum and other multiresistant non-diphtherial corynebacteria in paediatric oncology patients. Braz J Infect Dis 22:347-351. https://doi.org/10.1016/j. bjid.2018.07.004

Caumo K, Duarte M, Cargnin ST, Ribeiro VB, Tasca T, Macedo AJ (2010) Resistência bacteriana no meio ambiente e implicações na clínica hospitalar. Rev Liberato (Novo Hamburgo) 11:183-190

Chatzopoulou M, Koufakis T, Voulgaridi I, Gabranis I, Tsiakalou M (2016) A case of fatal sepsis due to multidrug-resistant Corynebacterium striatum. Hippokratia 20:67-69

Collada JM, Nieto AR, Ussia MDB, Criado AB (2018) Septic arthritis in a native knee due to Corynebacterium striatum. Reumatol Clin 14:301-302. https://doi.org/10.1016/j.reuma.2017.01.013

Cone LA, Curry N, Wuestoff MA, O'Connell SJ, Feller JF (1998) Septic synovitis and arthritis due to Corynebacterium striatum following an accidental scalpel injury. Clin Infect Dis 27:15321533. https://doi.org/10.1086/517737

Costerton JW, Stewart PS, Greenberg EP (1999) Bacterial biofilms: a common cause of persistent infections. Science 284:1318-1322. https://doi.org/10.1126/science.284.5418.1318

Costerton W, Veeh R, Shirtliff M, Pasmore M, Post C, Ehrlich G (2003) The application of biofilm science to the study of and control of chronic bacterial infections. J Clin Inv 112:1466-1477. https:// doi.org/10.1172/JCI20365

Cowling P, Hall L (1992) Corynebacterium striatum: a clinically significant isolate from sputum in chronic obstructive airways disease. J Infect 26:335-336. https://doi.org/10.1016/01634453(93)95823-2

Daisuke U, Oishi T, Yamane K, Terada K (2017) Corynebacterium striatum bacteremia associated with a catheter-related blood stream infection. Case Rep Infect Dis 2017:2682149. https:// doi.org/10.1155/2017/2682149

Dall L, Barnes WG, Hurford D (1989) Septicaemia in a granulocytopenic patient caused by Corynebacterium striatum. Postgrad Med J 65:247-248. https://doi.org/10.1136/pgmj.65.762.247

de Arriba JJ, Blanch JJ, Mateos F, Martínez-Alfaro E, Solera J (2002) Corynebacterium striatum first reported case of prosthetic valve endocarditis. J Infect 44:193-204. https://doi.org/10.1053/ jinf.2001.0927

Díez-Aguilar M, Ruiz-Garbajosa P, Fernández-Olmos A, Guisado P, Del Campo R, Quereda C, Cantón R, Meseguer MA (2013) Nondiphtheriae Corynebacterium species: an emerging respiratory pathogen. Eur J Clin Microbiol Infect Dis 32:769-772. https:// doi.org/10.1007/s10096-012-1805-5

Elshibly S, Xu J, Millar BC, Armstrong C, Moore JE (2006) Molecular diagnosis of native mitral valve endocarditis due to Corynebacterium striatum. Br J Biomed Sci 63:181-184. https://doi. org/10.1080/09674845.2006.11978096

Fernández Guerrero ML, Molins A, Rey M, Romero J, Gadea I (2012) Multidrug-resistant Corynebacterium striatum endocarditis successfully treated with daptomycin. Int J Antimicrob Agents 40:373-374. https://doi.org/10.1016/j.ijantimicag.2012.06.001

Fernández-Ayala M, Nan DN, Fariñas MC (2001) Vertebral osteomyelitis due to Corynebacterium striatum. Am J Med 111:167. https ://doi.org/10.1016/s0002-9343(01)00739-2

Fu-Lun C, Po-Ren H, Sing-On T, Tsong-Yih O, Wen-Sen L (2012) Corynebacterium striatum bacteremia associated with central 
venous catheter infection. J Microbiol Immunol Infect 45:255258. https://doi.org/10.1016/j.jmii.2011.09.016

Funke G, Bernard KA (2011) Coryneform gram-positive rods. In: Versalovic J (ed) Manual of clinical microbiology, 10th edn. ASMscience, Washington, pp 413-442

Gandham NR, Singh G, Roy I, Vyawahare C, Gooptu S, Jadhav SV, Misra RN (2013) Necrotizing fasciitis of lower limb by Corynebacterium striatum in a HBsAg positive patient. Int J Med Clin Res 4:242-244. https://doi. org/10.9735/0976-5530.4.1.242-244

Ge Y, Lu J, Feng S, Ji W, Tong H (2020) A case of catheter related bloodstream infection by Corynebacterium striatum. IDCases 22:e00987. https://doi.org/10.1016/j.idcr.2020.e00987

Gehlhausen J, Strausburg MB, Gilbert KE, Alomari AK (2018) Early botryomycosis-like plaques in the setting of Corynebacterium striatum septicemia. Int J Dermatol 58:969-971. https://doi. org/10.1111/ijd.14162

Gili NJ, Noren T, Törnquist E, Crafoord S, Bäckman A (2018) Preoperative preparation of eye with chlorhexidine solution significantly reduces bacterial load prior to 23-gauge vitrectomy in Swedish health care. BMC Ophthalmol 18:167. https://doi.org/10.1186/ s12886-018-0844-9

Hagiya H, Kimura K, Okuno H, Hamaguchi S, Morii D, Yoshida H, Mitsui T, Nishi I, Tomono K (2019) Bacteremia due to high-level daptomycin-resistant Corynebacterium striatum: A case report with genetic investigation. J Infect Chemother 25:906-908. https ://doi.org/10.1016/j.jiac.2019.04.009

Heidemann DG, Dunn SP, Diskin JA, Aiken TB (1991) Corynebacterium striatum keratitis. Cornea 10:81-82

Hollnagel K, Willen J, Ellis M, Soleimanifard Y, Booth R, Nandi S (2020) Chronic Corynebacterium striatum septic arthritis in a patient referred for total knee arthroplasty. Case Rep Orthop 2020:1392182. https://doi.org/10.1155/2020/1392182

Howie R, Alfa MJ, Coombs K (2008) Survival of enveloped and nonenveloped viruses on surfaces compared with other micro-organisms and impact of suboptimal disinfectant exposure. J Hosp Infec 69:368-376. https://doi.org/10.1016/j.jhin.2008.04.024

Hyo-Lim H, Hwi-In K, A-Jin L (2016) Native valve endocarditis due to Corynebacterium striatum confirmed by $16 \mathrm{~S}$ ribosomal RNA sequencing: a case report and literature review. Infect Chemother 48:239-245. https://doi.org/10.3947/ic.2016.48.3.239

Iaria C, Stassi G, Costa GB, Biondo C, Gerace E, Noto A, Spinella SG, David A, Cascio A (2007) Outbreak of multi-resistant Corynebacterium striatum infection in an Italian general intensive care unit. J Hosp Infect 67:102-104. https://doi. org/10.1016/j.jhin.2007.07.002

Ishiwada N, Watanabe M, Murata S, Takeuchi N, Taniguchi T, Igari H (2016) Clinical and bacteriological analyses of bacteremia due to Corynebacterium striatum. J Infect Chemother 22:790-793. https://doi.org/10.1016/j.jiac.2016.08.009

Jagadeeshan N, Jayaprakash S, Ramegowda RT, Manjunath CN, Lavanya V (2016) An unusual case of Corynebacterium striatum endocarditis in a patient with congenital lymphedema and rheumatic heart disease. Indian Heart J 68:S271-S273. https:// doi.org/10.1016/j.ihj.2015.07.026

Jorgensen JH, Pfaller MA, Carroll KC, Funke G, Landry ML, Richter SS, Warnock DW (2015) Manual of clinical microbiology, 11th edn. ASMscience, Washington

Juurlink DN, Borczyk A, Simor AE (1996) Native valve endocarditis due to Corynebacterium striatum. Eur J Clin Microbiol Infect Dis 15:963-965. https://doi.org/10.1007/BF01690520

Kammoun MM, Regaieg K, Bahloul M, Ammar R, Bouaziz M (2016) Corynebacterium striatum meningitis. Med Mal Infect 46:454456. https://doi.org/10.1016/j.medmal.2016.06.007

Keijman JMG, Luirink MR, Ratnsay G, Jacobs JA (2000) Native valve endocarditis due to Corynebacterium striatum. Clin
Microbiol Newsl 22:125-127. https://doi.org/10.1016/S0196 $-4399(01) 80002-7$

Lee PP, Ferguson DA Jr, Sarubbi FA (2005) Corynebacterium striatum: an underappreciated community and nosocomial pathogen. J Infect 50:338-343. https://doi.org/10.1016/j. jinf.2004.05.005

Lehmann KB, Neumann RO (1896) Atlas und grundriss der bakteriologie und lehrbuch der speziellen bakteriologischen diagnostic, 1st edn. Lehmann JF, München, p 1907

Lewis DL, Arens M (1995) Resistance of microorganisms to disinfection in dental and medical devices. Nat Med 1:956-958. https:// doi.org/10.1038/nm0995-956

López AB, Ruiza MTG, Prado LV, Olivares MF (2009) Cistitis y hematuria por Corynebacterium striatum. A propósito de un caso y revisión de la literatura científica. Actas Urol Esp 33:909-912. https://doi.org/10.1016/s0210-4806(09)72880-3

Lorena NOS, Duarte RS, Pitombo MB (2009) Infecção por micobactérias de crescimento rápido após procedimentos videocirúrgicosa hipótese do glutaraldeído. Rev Col Bras Cir 36:266-267. https ://doi.org/10.1590/S0100-69912009000300015

Markowitz SM, Coudron PE (1990) Native valve endocarditis caused by an organism resembling Corynebacterium striatum. J Clin Microbiol 28:8-10. https://doi.org/10.1128/JCM.28.1.8-10.1990

Martín MC, Melón O, Celada MM, Alvarez J, Méndez FJ, Vázquez F (2003) Septicaemia due to Corynebacterium striatum: molecular confirmation of entry via the skin. J Med Microbiol 52:599-602. https://doi.org/10.1099/jmm.0.05102-0

Martínez-Martínez L, Suárez AI, Ortega MC, Rodríguez-Jiménez R (1994) Fatal pulmonary infection caused by Corynebacterium striatum. Clin Infect Dis 19:806-807. https://doi.org/10.1093/ clinids/19.4.806

Martins CAS, Faria LMD, Souza MC, Camello TCF, Velasco E, Hirata R Jr, Thuler LCS, Mattos-Guaraldi AL (2009) Microbiological and host features associated with corynebacteriosis in cancer patients: a five-year study. Mem Inst Oswaldo Cruz 104:905913. https://doi.org/10.1590/S0074-02762009000600015

McDonnell GE (2007) Antisepsis, disinfection, and sterilization: types, action, and resistance, 2nd edn. ASMscience, Washington

McDonnell G, Russell AD (1999) Antisepsis and disinfection: action, and resistance. Clin Microbiol Rev 12:147-179. https://doi. org/10.1128/CMR.12.1.147

Mitsugui CS, Tognim MCB, Carrara-Marrone FE, Garcia LB (2008) The in vitro antimicrobial effect of polymyxin B associated with ceftazidime in Pseudomonas aeruginosa clinical isolates. Ciênc Cuid Saúde 7:76-81. https://doi.org/10.1016/j.ijantimica g.2011.06.012

Moore K, Hall V, Paull A, Morris T, Brown S, McCulloch D, Richardson MC, Harding KG (2010) Surface bacteriology of venous leg ulcers and healing outcome. J Clin Pathol 63:830-834. https:// doi.org/10.1136/jcp.2010.077032

Oliva A, Belvisi V, Iannetta M, Andreoni C, Mascellino MT, Lichtner M, Vullo V, Mastroianni CM (2010) Pacemaker lead endocarditis due to multidrug-resistant Corynebacterium striatum detected with sonication of the device. J Clin Microbiol 48:4669-4671. https://doi.org/10.1128/JCM.01532-10

Oliveira AC, Damasceno QS, Ribeiro SMCP (2009) Healthcare-associated infection: challenges in its prevention and control. Rev Min Enf 13:445-450

Otsuka Y, Ohkusu K, Kawamura Y, Baba S, Ezaki T, Kimura S (2006) Emergence of multidrug-resistant Corynebacterium striatum as a nosocomial pathogen in long-term hospitalized patients with underlying diseases. Diagn Microbiol Infect Dis 54:109-114. https://doi.org/10.1016/j.diagmicrobio.2005.08.005

Parte AC (2014) LPSN-list of prokaryotic names with standing in nomenclature. Nucleic Acids Res 1:D613-D616. https://doi. org/10.1093/nar/gkt1111 
Pimenta FP, Souza MC, Pereira GA, Hirata R Jr, Camello TC, Mattos-Guaraldi AL (2008) DNase test as a novel approach for the routine screening of Corynebacterium diphtheria. Lett Appl Microbiol 46:307-311. https://doi.org/10.1111/j.1472765X.2007.02310.X

Psaltikidis EM, Leichsenring ML, Nakamura MHY, Bustorff-Silva JM, Passeri LA, Venâncio SI (2014) High-level disinfectants alternative to glutaraldehyde for processing flexible endoscopes. Cogitare Enferm 19:423-432

Ramos JN, Souza C, Faria YV, Silva EC, Veras JFC, Baio PVP, Seabra SH, Moreira LO, Hirata R Jr, Mattos-Guaraldi AL, Vieira VV (2019) Bloodstream and catheter-related infections due to different clones of multi-drug resistant and biofilm producer Corynebacterium striatum. BMC Infect Dis 19:672. https://doi. org/10.1186/s12879-019-4294-7

Reddy BS, Chaudhury A, Kalawat U, Jayaprada R, Reddy G, Ramana BV (2012) Isolation, speciation, and antibiogram of clinically relevant non-diphtherial corynebacteria (Diphtheroids). Indian J Med Microbiol 30:52-57. https://doi. org/10.4103/0255-0857.93033

Renom F, Garau M, Rubí M, Ramis F, Galmés A, Soriano JB (2007) Nosocomial outbreak of Corynebacterium striatum infection in patients with chronic obstructive pulmonary disease. J Clin Microbiol 45:2064-2067. https://doi.org/10.1128/JCM.00152-07

Roig-Rico P, Safont-Gaso P, Marín-Tordera D, la Tabla VOD (2011) Corynebacterium striatum pneumonia in an HIV patient. Enferm Infecc Microbiol Clin 29:402. https://doi.org/10.1016/j. eimc.2011.02.005

Rufael DW, Cohn SE (1994) Native valve endocarditis due to Corynebacterium striatum: case report and review. Clin Infect Dis 19:1054-1061. https://doi.org/10.1093/clinids/19.6.1054

Rutala WA, MPH, CIC (1994, 1995, 1996 APIC Committee) (1996) APIC guideline for selection and use of disinfectants. Am J Infect Control 24:313-342. https://doi.org/10.1016/S0196 -6553(96)90066-8

Rutala WA, Weber DJ (2008) The Healthcare Infection Control Practices Advisory Committee (HICPAC) Guideline for disinfection and sterilization in healthcare facilities, 2008. Center for diseases control and prevention. Diag Microb, North Carolina, pp 6

Santos NQ (2004) Bacterial resistence in the context of hospital infection. Texto Contexto Enferm 13:64-70. https://doi.org/10.1590/ S0104-07072004000500007

Sattar SA, Springthorpe VS (2001) New methods for efficacy testing of disinfectants and antiseptics. In: Rutala WA (ed) Disinfection, sterilization and practices in healthcare facilities. Assoc Infect Cont Epid, Washington, pp 80-86

Savini V, Gherardi G, Favaro M, Fontana C, Marrollo R, Argentieri AV, Dicuonzo G, Fazii P, D'Antonio D (2013) About a bloodstream Corynebacterium striatum isolate. Folia Microbiol 58:451-453. https://doi.org/10.1007/s12223-013-0227-9

Scholle D (2007) A spontaneous joint infection with Corynebacterium striatum. J Clin Microbiol 45:656-658. https://doi.org/10.1128/ JCM.00827-06

Schröder J, Maus I, Meyer K, Wördemann S, Blom J, Jaenicke S, Schneider J, Trost E, Tauch A (2012) Complete genome sequence, lifestyle, and multi-drug resistance of the human pathogen Corynebacterium resistens DSM 45100 isolated from blood samples of a leukemia patient. BMC Genomics 23:141. https:// doi.org/10.1186/1471-2164-13-141

Severo CB, Guazzelli LS, Barra MB, Hochhegger B, Severo LC (2014) Multiple pulmonary nodules caused by Corynebacterium striatum in an immunocompetent patient. Rev Inst Med Trop São Paulo 56:89-91. https://doi.org/10.1590/S0036-4665201400 0100015

Shadid MB, Speth MJGM, Voorn GP, Wolterbeek N (2019) Chlorhexidine $0.5 \% / 70 \%$ alcohol and iodine $1 \% / 70 \%$ alcohol both reduce bacterial load in clean foot surgery: a randomized, controlled trial. J Foot Ankle Surg 58:278-281. https://doi. org/10.1053/j.jfas.2018.08.042

Silva F, Lima F, Ferreira AM, Colombo TE, Rubio FG, Almeida MTG (2013) Fungal contamination of hospital mattresses before and following cleaning and disinfection. Acta Paul Enferm 26:485-491. https://doi.org/10.1590/S0103-21002 013000500013

Simpson-Lourêdo L, Silva CMF, Hacker E, Souza NF, Santana MM, Antunes CA, Nagao PE, Hirata R Jr, Burkovski A, Villas Bôas MHS, Mattos-Guaraldi AL (2019) Detection and virulence potential of a phospholipase D-negative Corynebacterium ulcerans from a concurrent diphtheria and infectious mononucleosis case. Antonie Van Leeuwenhoek 112:1055-1065. https://doi. org/10.1007/s10482-019-01240-4

Soares MA (2001) Resistência antibiótica. Pharm Bras pp 59-62

Souza ACS, Pereira MS, Rodrigues MAV (1998) Descontaminação prévia de materiais médico-cirúrgicos: estudo da eficácia de desinfetantes químicos e água e sabão. Rev Latino-Am Enf 6:95-105. https://doi.org/10.1590/S0104-11691998000300012

Souza C, Faria YV, Sant'Anna LO, Viana VG, Seabra SH, Souza MC, Vieira VV, Hirata R Jr, Moreira LO, Mattos-Guaraldi AL (2015) Biofilm production by multi-resistant Corynebacterium striatum associated with nosocomial outbreak. Mem Inst Oswaldo Cruz 110:242-248. https://doi.org/10.1590/0074-02760140373

Souza C, Simpson-Louredo L, Mota HF, Faria YV, Cabral FO, Colodette SS, Canellas MEFC, Cucinelli AES, Luna MG, Santos CS, Moreira LO, Mattos-Guaraldi AL (2019) Virulence potential of Corynebacterium striatum towards Caenorhabditis elegans. Antonie Van Leeuwenhoek 112:1331-1340. https://doi. org/10.1007/s10482-019-01265-9

Souza C, Mota HF, Faria YV, Cabral FO, Oliveira DR, Sant'Anna LO, Nagao PE, Santos CS, Moreira LO, Mattos-Guaraldi AL (2020) Resistance to antiseptics and disinfectants of planktonic and biofilm-associated forms of Corynebacterium striatum. Microb Drug Resist 26:1546-1558. https://doi.org/10.1089/ mdr.2019.0124

Stoddart B, Sandoe JA, Denton M (2005) Corynebacterium striatum endocarditis masquerading as connective tissue disorders. Rheumatology (Oxford) 44:557-558. https://doi.org/10.1093/rheum atology/keh519

Stone N, Gillett P, Burge S (1997) Breast abscess due to Corynebacterium striatum. Br J Dermatol 137:623-625. https://doi. org/10.1111/j.1365-2133.1997.tb03799.x

Superti SV, Martins DS, Caierão J, Soares F, Prochnow T, Cantarelli VV, Zavascki AP (2009) Corynebacterium striatum infecting a malignant cutaneous lesion: the emergence of an opportunistic pathogen. Rev Inst Med Trop S Paulo 51:115-116. https://doi. org/10.1590/S0036-46652009000200011

Svetlíková Z, Skovierová H, Niederweis M, Gaillard JL, McDonnell G, Jackson M (2009) Role of porins in the susceptibility of Mycobacterium smegmatis and Mycobacterium chelonae to aldehydebased disinfectants and drugs. Antimicrob Agents Chemother 53:4015-4018. https://doi.org/10.1128/AAC.00590-09

Tarr PE, Stock F, Cooke RH, Fedorko DP, Lucey DR (2003) Multidrug-resistant Corynebacterium striatum pneumonia in a heart transplant recipient. Transpl Infect Dis 5:53-58. https://doi.org/ 10.1034/j.1399-3062.2003.00002.x

Torres LFC, Ribeiro D, Hirata R Jr, Pacheco LGC, Souza MC, Santos LS, Santos CS, Salah M, Costa MM, Ribeiro MG, Selim SA, Azevedo VAC, Mattos-Guaraldi AL (2013) Multiplex polymerase chain reaction to identify and determine the toxigenicity of Corynebacterium spp. with zoonotic potential and an overview of human and animal infections. Mem Inst Oswaldo Cruz 108:272-279. https://doi.org/10.1590/S0074-027620130003000 03 
Trost E, Al-Dilaimi A, Papavasiliou P, Schneider J, Viehoever P, Burkovski A, Soares SC, Almeida SS, Dorella FA, Miyoshi A, Azevedo V, Schneider MP, Silva A, Santos CS, Santos LS, Sabbadini P, Dias AA, Hirata R Jr, Mattos-Guaraldi AL, Tauch A (2011) Comparative analysis of two complete Corynebacterium ulcerans genomes and detection of candidate virulence factors. BMC Genomics 12:383. https://doi.org/10.1186/1471-2164-12-383

Vermelho AB, Bastos MCF, Branquinha de Sá MH (2008) Bacteriologia Geral, 1st edn. Guanabara Koogan, Rio de Janeiro

Verroken A, Bauraing C, Deplano A, Bogaerts P, Huang D, Wauters G, Glupczynski Y (2014) Epidemiological investigation of a nosocomial outbreak of multidrug-resistant Corynebacterium striatum at one Belgian university hospital. Clin Microbiol Infect 20:44-50. https://doi.org/10.1111/1469-0691.12197

Wang X, Zhou H, Chen D, Du P, Lan R, Qiu X, Hou X, Liu Z, Sun L, Xu S, Ji X, Li H, Li D, Zhang J, Zeng H, Li Z (2019) Wholegenome sequencing reveals a prolonged and persistent intrahospital transmission of Corynebacterium striatum, an emerging multidrug-resistant pathogen. J Clin Microbiol 57:e0683-e719. https://doi.org/10.1128/JCM.00683-19

Weiss K, Labbé AC, Laverdière M (1996) Corynebacterium striatum meningitis: case report and review of an increasingly important Corynebacterium species. Clin Infect Dis 23:1246-1248. https ://doi.org/10.1093/clinids/23.6.1246

Westblade LF, Shams F, Duong S, Tariq O, Bulbin A, Klirsfeld D, Zhen W, Sakaria S, Ford BA, Burnham CAD, Ginocchio CC
(2014) Septic arthritis of a native knee joint due to Corynebacterium striatum. J Clin Microbiol 52:1786-1788. https://doi. org/10.1128/JCM.02641-13

Widmer AE, Frei R (2003) Antimicrobial activity of glucoprotamin: a clinical study of a new disinfectant for instruments. Infect Control Hosp Epidemiol 24:762-764. https://doi.org/10.1086/502128

Wong KY, Chan YC, Wong CY (2010) Corynebacterium striatum as an emerging pathogen. J Hosp Infect 76:371-372. https://doi. org/10.1038/s41598-017-10081-y

Yoo G, Kim J, Uh Y, Lee HG, Hwang GY, Yoon KJ (2015) Multidrug-resistant Corynebacterium striatum bacteremia: first case in Korea. Ann Lab Med 35:472-473. https://doi.org/10.3343/ alm.2015.35.4.472

Yoon S, Kim H, Lee Y, Kim S (2011) Bacteremia caused by Corynebacterium amycolatum with a novel mutation in gyrA gene that confers high-level quinolone resistance. Korean J Lab Med 31:47-48. https://doi.org/10.3343/kjlm.2011.31.1.47

Zasada AA, Mosiej E (2018) Contemporary microbiology and identification of Corynebacteria spp. causing infections in human. Lett Appl Microbiol 66:472-483. https://doi.org/10.1111/lam.12883

Publisher's Note Springer Nature remains neutral with regard to jurisdictional claims in published maps and institutional affiliations. 